\title{
Mimicking biological principles in artificial olfactory system
}

\author{
Baranidharan Raman \\ From 1st International Workshop on Odor Spaces \\ Hannover, Germany. 4-7 September 2013
}

Biology has inspired solutions to many engineering problems, including those encountered in chemical sensing. Modern approaches to chemical sensing have been based on the biological principle of combining cross-selective chemical sensors with a pattern recognition engine to identify odors. In this poster, we will review some recent advances made by our group in mimicking biological design and computing principles to develop a neuromorphic electronic nose.

Published: 16 April 2014

doi:10.1186/2044-7248-3-S1-P24

Cite this article as: Raman: Mimicking biological principles in artificial

olfactory system. Flavour 2014 3(Suppl 1):P24.

- No space constraints or color figure charges

- Immediate publication on acceptance

- Inclusion in PubMed, CAS, Scopus and Google Scholar

- Research which is freely available for redistribution 